\title{
Flow cytometry-based evaluation of the bacterial removal efficiency of a blackwater reuse treatment plant and the microbiological changes in the associated non-potable distribution network
}

Rachel Whitton ${ }^{\mathrm{a}}$, Sarah Fane ${ }^{\mathrm{a}}$, Peter Jarvis ${ }^{\mathrm{a}}$, Martyn Tupper $^{\mathrm{b}}$, Marie Raffin ${ }^{\mathrm{b}}$, Frédéric Coulon $^{\mathrm{a}}$ and Andreas Nocker ${ }^{\mathrm{a}, \mathrm{c}^{*}}$

${ }^{a}$ Cranfield University, School of Water, Energy and Environment, Cranfield University, Cranfield, Bedfordshire MK43 OAL, United Kingdom

${ }^{\mathrm{b}}$ Thames Water Utilities Ltd, Clearwater Court, Vastern Road, Reading, Berkshire RG1 8DB, United Kingdom

IWW Water Centre; Moritzstraße 26, 45476 Mülheim an der Ruhr, Germany *corresponding author: andreas.nocker@gmail.com

\section{Abstract}

The study evaluated the changes in bacterial numbers across a full-scale membrane bioreactor (MBR) blackwater reuse system. Flow cytometry was used to quantify total and intact bacterial concentrations across the treatment train and during distribution of the recycled water. Membrane passage reduced bacterial numbers by up to 5 -log units resulting in coliform-free permeate. A 2-log increase in bacterial cell concentration was subsequently observed after the granular activated carbon unit followed by a reduction in intact cells after chlorination, which corresponds to an overall intact bacteria removal of 3.4-log units. In the distribution network, the proportion of intact cells greatly depended on the free chlorine residual, with decreasing residual enabling regrowth. An initial target of $0.5 \mathrm{mg} \mathrm{L}^{-1}$ free chlorine ensured sufficient suppression of intact cells for up to 14 days (setting the time intervals for system flushes at times of low water usage). Bacterial regrowth was only observed when the free chlorine concentration 
was below $0.34 \mathrm{mg} \mathrm{L}^{-1}$. Such loss of residual chlorine mainly applied to distant points in the distribution network from the blackwater reuse treatment plant (BRTP). Flushing these network points for 5 mins did not substantially reduce cell numbers. At points closer to the BRTP, on the other hand, flushing reduced cell numbers by up to 1.5-log units concomitant with a decreasing proportion of intact cells. Intact cell concentrations did not correlate with DOC, total nitrogen, or soluble reactive phosphate, but it was shown that dead biomass could be efficiently converted into new biomass within seven days.

Keywords: Blackwater reuse; water recycling; MBR; distribution system; chlorination; flow cytometry

\section{Introduction}

Mitigation measures to ensure water supply security are not limited to water-deficient areas, but are also increasingly applied in a growing number of countries that are not per se located in arid climatic regions. The reasons for this are related to rapidly expanding urban areas placing significant demands and stresses on local water resources, combined with changing weather patterns and longer lasting droughts (Angelakis and Gikas 2014). Water reuse is therefore increasingly on the political agenda and treatment technologies are being developed to ensure high water quality standards are met. Among different wastewater types, blackwater (or greywater containing a proportion of blackwater due to lack of separation) represents one the most available water sources whose use is increasingly sustainable (Hurlimann et al. 2007). The majority of blackwater comes from households and contains a mixture of faecal material, urine and toilet paper with high amounts of organic matter, microorganisms, nitrogen and phosphate. When blackwater is reused, it is typically not 
treated to potable water standards due to the belief that the public are not supportive of its direct reuse. However, recent studies contradict these assumptions and have demonstrated increasing acceptance (Smith et al. 2015; Goodwin et al. 2017). Presently the treatment of blackwater to a high quality water that meets (or exceeds) standards are typically used in cooling towers, irrigation systems and for toilet flushing. Membrane bioreactors (MBR) are very appropriate treatment systems in achieving high effluent qualities for chemical and microbiological parameters (Huang et al. 2016; Knerr et al. 2011).

Whenever blackwater is reused, the treated water quality is carefully monitored to ensure its safety. Depending on water usage and regional legislation, treatment and monitoring requirements are different. Apart from monitoring the operating parameters of individual multi-barrier treatment steps, the minimal common denominator of water quality monitoring comprises measuring levels of faecal indicators, $\mathrm{BOD}$, turbidity and conductivity in addition to ensuring a sufficient level of disinfection (US EPA, 2004; Quevauviller et al. 2007). One of the greatest challenges for microbiological water quality monitoring is the time needed to investigate the water safety. By the time analysis results are available, the water is in part already distributed and used (Højris et al. 2016). This problem especially applies to traditional cultivation-based analysis whose speed is inevitably determined by the growth rate of the microorganism to be counted. Rapid analytical methods are therefore much sought after to fully meet water safety requirements and to quickly determine with high sensitivity any potential fault in the treatment process or any quality deterioration during distribution.

In this study flow cytometry (FCM) was applied as a rapid method for monitoring general microbiological water quality of distributed water (Prest et al. 2013 and 2016) and to evaluate disinfection efficiency (Berney et al. 2007; Ramseier et al. 2011). The technology has mainly been applied to monitor drinking water systems (Hammes et al. 
2008 and 2012; Besmer et al. 2016) with only recent examples evaluating water reuse schemes (Huang et al. 2016). The aim of this study was to quantitatively assess the efficiency of bacterial removal in a full-scale MBR blackwater reuse treatment plant in the UK and the change in bacterial numbers during distribution throughout the dedicated distributed network. The work was performed at the Old Ford Water Recycling Plant, the UK's largest water recycling plant (WRP). The plant abstracts raw municipal and light commercial wastewater from the Northern Outfall Sewer (Hill and James, 2014). The treated water serves for direct non-potable use (irrigation and toilet flushing) for the Queen Elizabeth Olympic Park which hosted the London Olympic Games in 2012.

\section{Materials and Methods}

\subsection{Description of the Old Ford WRP and sampling procedure}

The Old Ford WRP is a multi-barrier treatment process, treating raw wastewater composed of domestic and light commercial sewage, including surface runoff, from a catchment of 360,000 PE. The source wastewater is abstracted from the Northern Outfall Sewer and treated to standards based on the USEPA guidelines for 'unrestricted urban reuse' (US EPA, 2004) in addition to further water quality criteria specified by the venue operators located within the Olympic Park (Hill and James, 2014). The Old Ford WRP is able to achieve an average treated flow of $574 \mathrm{~m}^{3} \mathrm{~d}^{-1}$, with the ability to meet an estimated peak day flow of $813 \mathrm{~m}^{3} \mathrm{~d}^{-1}$ through on-site storage (Knight et al. 2012).

The Old Ford WRP multi-barrier treatment process consists of pre-treatment within underground septic tanks for the removal of rags and gross solids. The settled sewage then passes through a $1 \mathrm{~mm}$ screen for the removal of particulate matter (e.g. hair and 
fibres) prior to treatment within the MBR with a designed hydraulic retention time (HRT) of $14.9 \mathrm{~h}$, sludge retention time (SRT) of approximately 27 days and operational temperature range of 5 to $35^{\circ} \mathrm{C}$ (Hill and James, 2014). The MBR consists of two units: an externally located above-ground activated sludge tank, with segregated anoxic and aerobic zones, containing mixed liquor suspended solids (MLSS); and an internally located unit containing three racks of cross-flow ultrafiltration membranes (UF) of a nominal pore size of $0.04 \mu \mathrm{m}$. Membrane fouling is mitigated through pulsated air scouring and periodic cleaning in place $\left(1,500 \mathrm{mg} \cdot \mathrm{L}^{-1}\right.$ of $\mathrm{NaOCL}$ every 90 days for 6 to 7 hours). In addition, maintenance washes of $300 \mathrm{mg} \cdot \mathrm{L}^{-1} \mathrm{NaOCL}$ over a 45 minute period are undertaken every seven days (Hill and James, 2014). Treated MBR effluent undergoes post-treatment to remove remaining water colour and organic matter, through filtration and adsorption in granular activated carbon (GAC) vessels prior to a final disinfection step with sodium hypochlorite to provide a chlorine $(\mathrm{Cl})$ residual ranging between 0.3 and $1.5 \mathrm{mg} \mathrm{L}^{-1}$ prior to storage and distribution (Figure 1). Further details of the Old Ford WRP can be found in Hill and James (2014).

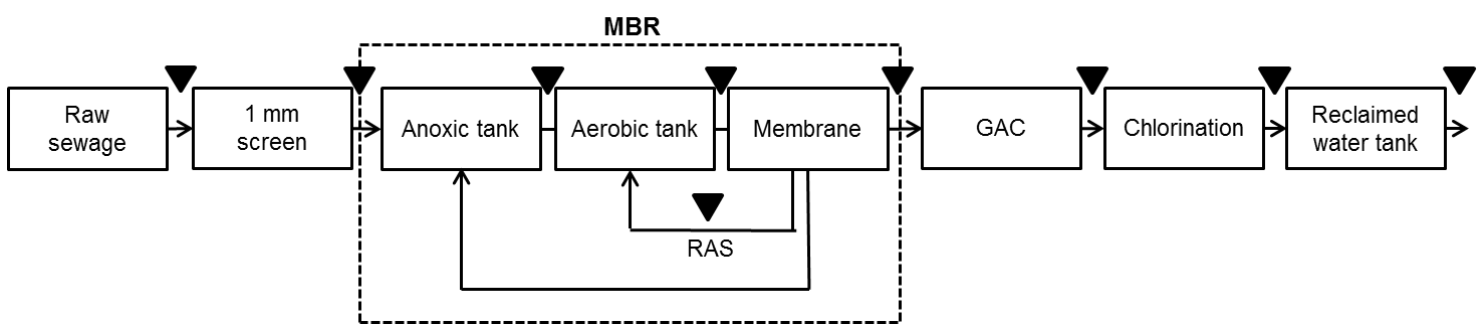

Figure 1. Diagrammatic representation of the treatment train at Old Ford WRP with sampling points identified. RAS: Return Activated Sludge, GAC: Granular Activated Carbon; MBR: Membrane Bioreactor. Triangles indicate where samples were taken.

Grab samples were collected via designated continuously running sampling taps through the Old Ford WRP treatment train (Figure 1). The sampling was carried out every 1-3 months over the period from March 2015 to March 2016. Samples were 
collected in $100 \mathrm{~mL}$ sterile sampling bottles (Aurora Scientific, UK). Bottles pre-dosed with thiosulfate were used for the collection of samples following the chlorination stage to eliminate any residual disinfectant. Samples were transported at $4^{\circ} \mathrm{C}$ and analysed by FCM within 24 hours of collection.

\subsection{Description of non-potable distribution network and sampling procedure}

Treated effluent from the Old Ford WRP is distributed throughout the Queen Elizabeth Olympic Park within a dedicated $3.65 \mathrm{~km}$ distribution network composed of polyethylene (PE) pipes with internal diameters of $63 \mathrm{~mm}$ to $180 \mathrm{~mm}$ (Hill and James, 2014). Six points were sampled across the length of the network (Figure 2) supplying numerous venues and park facilities, varying in end point use (i.e. toilet flushing, irrigation, supplementing rainwater harvesting systems) and proximity to the Old Ford WRP (Table 1). Two further network points, which were not sampled during the project, but utilised during network flushing maintenance activities, are identified as Network Flush Point A and B within Figure 2, respectively.

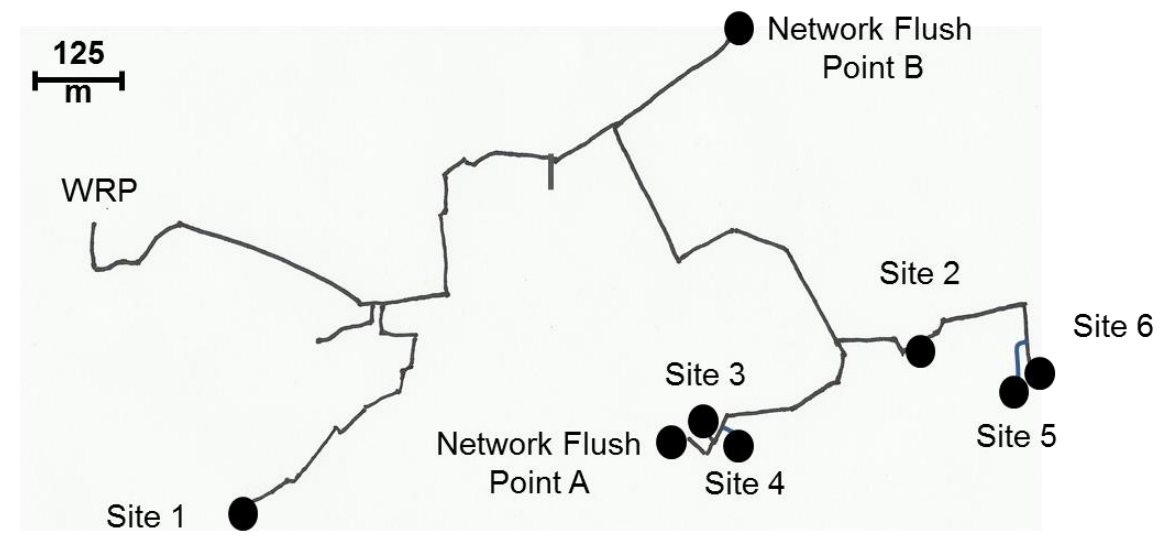

Figure 2. The non-potable distribution network sampling points and network flush points (diagram not drawn to scale). 
Table 1. Non-potable distribution network details including approx. distance from WRP and approx. pipe volume.

\begin{tabular}{lcc}
\hline $\begin{array}{l}\text { Network sample } \\
\text { point }\end{array}$ & $\begin{array}{c}\text { Approx. pipe distance } \\
\text { from Old Ford WRP }(\mathbf{m})\end{array}$ & $\begin{array}{c}\text { Approx. pipe } \\
\text { volume }\left(\mathbf{m}^{3}\right)\end{array}$ \\
\hline Site 1 & 1,070 & 18.6 \\
Site 2 & 1,915 & 32.9 \\
Site 3 and Site 4 & 2,110 & 34.6 \\
Site 5 and Site 6 & 2,490 & 37.4 \\
\hline
\end{tabular}

\subsubsection{Network tap flush and sampling procedure}

Grab samples for FCM analysis were collected at intervals of 1-6 months over the period from March 2015 to January 2016 (referred to as spring/summer for samples collected between March-August and autumn/winter for samples collected between September-January). Sampling the network at a consistent and regular frequency was hampered by the availability of network operators to supervise sampling and undertake network flushing activities. As such, conclusions drawn through the study are based on the best available information obtained during the period of the study.

Samples were collected in sterile $100 \mathrm{~mL}$ sample bottles pre-dosed with thiosulfate (Aurora Scientific, UK) to eliminate residual chlorine $(\mathrm{Cl})$. Samples were collected according to Thames Water Utilities Ltd in-house sampling methodology, with samples collected prior to and post flushing of the sample tap. Firstly, the tap was marginally opened and allowed to flush for 30 seconds before sampling the pre-flush sample. The tap was subsequently treated with concentrated sodium hypochlorite and fully opened to flush for a further 5 minutes before collecting a post-flush tap sample. Samples were transported at $4^{\circ} \mathrm{C}$ and analysed by FCM within 24 hours of collection.

\subsubsection{Network maintenance flush and sampling procedure}

The network maintenance flush protocols performed by Thames Water are tailored for the spring/summer and autumn/winter periods through the associated high and low demand of the non-potable distribution network. As such the autumn/winter network 
flush is characterised by a high washout of approximately $20 \mathrm{~m}^{3} \mathrm{~h}^{-1}$ over a period of 20-30 minutes in comparison to a milder spring/summer flush of approximately $5 \mathrm{~m}^{3} \mathrm{~h}^{-1}$ for $<15$ minutes.

Network flushes are typically completed on the distal points of the network in order of Site 1, Network Flush Point A, Network Flush Point B, and Site 5 (Figure 2), however during the autumn/winter period the flushing protocol was completed on all sample points. Sampling of the network, with both pre-tap flush and post-tap flush samples were completed around these flushing events (Figure 3).

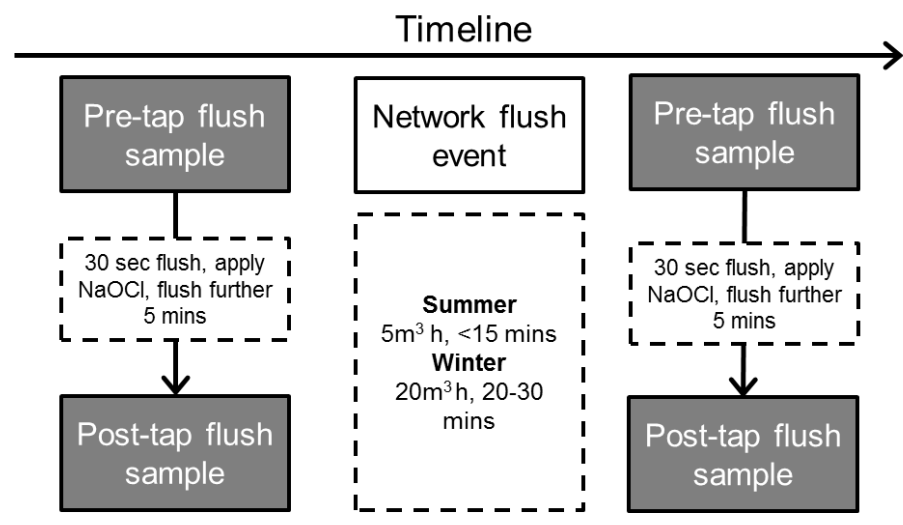

Figure 3. Schematic representation of sampling scenarios for individual sample taps.

\subsection{Assessment of regrowth potential}

Additional samples were collected from the distribution network for the analysis of regrowth potential. Pre-treatment of $30 \mathrm{~mL}$ glass vials and PTFE faced rubber lined caps (Fisher Scientific, 11593532) were completed following the method of Hammes and Egli (2007) for the elimination of residual organic carbon. Vials were pre-dosed with $0.2 \mathrm{~mL}$ of $0.1 \mathrm{~N}$ sodium-thiosulfate (Acros Organics by Thermos Fischer Scientific, Geel, Belgium) to eliminate remaining $\mathrm{Cl}$ residual, then filled with approximately $15 \mathrm{~mL}$ of sample and transported to the laboratory at $4^{\circ} \mathrm{C}$. Upon arrival, vials were capped with Parafilm ${ }^{\circledR}$ to allow gas exchange, and incubated at $22^{\circ} \mathrm{C}$ for seven days prior to FCM analysis. 


\subsection{Standard network parameters}

Free and total $\mathrm{Cl}$ residuals were measured at the time of sampling, using a 'Compact Chlorometer Duo' (Palintest, UK) following the manufacturers guidelines. Water use data reported as $\mathrm{m}^{3} \mathrm{~d}^{-1}$ was acquired from FUSION, an online database which collates water usage data received from the automated meter readings (AMR) associated to the individual network points. An estimate of water age was made by calculation from water use data and approximate pipe volumes (Table 1).

\subsection{Fluorescent staining and flow cytometry analysis}

Serial dilution of samples collected from the treatment train prior to ultrafiltration was undertaken prior to fluorescent staining due to high cell concentrations exceeding $10^{6}$ cells $\mathrm{mL}^{-1}$. Serial dilutions were made using $0.22 \mu \mathrm{m}$ filtered mineral water (Evian, Evian-les-Bains, France) as a diluent. Serial dilutions of all other samples from the treatment train (after ultrafiltration) and the non-potable distribution network (except the ones after regrowth) were unnecessary as the cell concentration was much lower $\left(10^{3}\right.$ $10^{5}$ cells $\mathrm{mL}^{-1}$ ).

Fluorescent staining protocols were similar to those of Gillespie et al. (2014) and Lipphaus et al. (2014). Staining for total cell concentration (TCC) was achieved through the fluorescent stain SYBR Green I (SG) $\left(10,000 \times\right.$ stock) $\left(\right.$ Invitrogen $\left.{ }^{\mathrm{TM}}\right)$ diluted to a working stock concentration of 100x using dimethyl sulphoxide (DMSO) (Fisher Scientific). The SG working stock was frozen $\left(-20^{\circ} \mathrm{C}\right)$ and concealed from light until use. To determine TCC values, $200 \mu \mathrm{L}$ water samples were added to the wells of a 96 well plate (Corning ${ }^{\circledR}$, (prod.nr. CL S3795)) with pre-aliquoted $2 \mu \mathrm{L}$ of the SG working stock followed by thorough mixing by pipetting up and down several times using a multichannel pipette. All samples were analysed at least in duplicate. To determine intact cell concentration (ICC) values, $200 \mu \mathrm{l}$ of water was stained with $2.4 \mu \mathrm{l}$ of a mixture of the working SG stock $(100 \mathrm{x})$ and $1 \mathrm{mg} \mathrm{mL}^{-1}$ propidium iodide (PI) (Fisher 
Scientific) in the ratio of 5:1. Preparation of fresh SG/PI dual stain mix was completed with the same staining procedure as described for TCC.

After mixing water samples with fluorescent dyes, the 96 well plates were placed in an enclosed microplate thermoshaker (PHMP, Grant Bio ${ }^{\mathrm{TM}}$ ) and incubated at $37^{\circ} \mathrm{C}$ for 13 min with mild rotation at $600 \mathrm{rpm}$. Following the incubation period, samples were analysed using a BD Accuri $6^{\circledR}$ flow cytometer (Becton Dickinson, UK) equipped with a $488 \mathrm{~nm}$ solid state laser. Signals from bacteria were separated from instrument noise and background by using a single fixed gate described by Gatza et al. (2013). Green fluorescence was collected in the FL-1 channel at $533 \mathrm{~nm}$ and the red fluorescence in the FL-3 channel at $670 \mathrm{~nm}$. The trigger was set on FL-1 with a threshold value of 2,000 units. Samples volumes of $25 \mu \mathrm{L}$ were analysed at a flow rate of $66 \mu \mathrm{L} \mathrm{min}{ }^{-1}$. Generated data was processed using the Accuri $\mathrm{C}^{\circledR}{ }^{\circledR}$ software. Regrowth potentials was measured by comparing ICC determined after incubating samples for 7 days at 22 ${ }^{\circ} \mathrm{C}$ with ICC at time point zero $(\mathrm{d}=0)$.

Following determination of TCC and ICC concentrations, log reductions were calculated using Equation 1 upon averaging the data from repeated measurements for each sample point within the treatment train.

$$
\text { Log reduction }=\log _{10}\left(\frac{\text { Average influent cells } \cdot m L^{-1}}{\text { Average effluent cells } \cdot m L^{-1}}\right) \quad \text { Equation } 1
$$

\subsection{Standard microbiological and water quality analysis}

Standard microbiological analysis was completed by Thames Water Utilities Ltd inhouse accredited laboratories for the quantification of heterotrophic bacteria, including faecal coliforms such as E.coli, through heterotrophic plate counts (HPC) and most probable number (MPN) method. Water quality data was analysed for a wide range of 
parameters, including but not limited to dissolved organic carbon (DOC), total organic carbon (TOC), total nitrogen (TN) and soluble reactive phosphorus (SRP).

\section{Results}

Overall microbiological water quality was assessed across the water treatment train and in the distribution network.

\subsection{Water recycling plant treatment performance}

Both TCC and ICC were determined after each step of the multi-barrier water treatment process. For the initial treatment steps, where samples comprised the liquid phase and no flocs, both TCC and ICC were around $10^{8}$ cells $\mathrm{mL}^{-1}$ (Figure 4). Neither mild sonication to disaggregate potentially any small clumps nor extension of the applied FCM gate produced greater cell numbers although it cannot be excluded that further sample processing might have made more cells available for analysis. Physical removal of biomass by membrane passage resulted in a large decrease in cell concentrations by up to 5 -log units. The E. coli concentration in the raw sewage reached an average concentration of $5 \times 10^{4} \mathrm{CFU} \mathrm{mL}^{-1}$, however none of these bacteria were found in the permeate. The permeate was also free of other coliforms (data not shown). Subsequent treatment through the GAC led to a 2-log increase in TCC and ICC. Total cell concentrations remained stable during disinfection (average residual $\mathrm{CI}$ concentration of $0.3-1.5 \mathrm{mg} \mathrm{L}^{-1}$ with a contact time of 30 mins), whereas the ICC dropped and remained low in the reclaimed water tank. The relative proportion of ICC was on average $5 \%$ and $9 \%$ directly after disinfection or in reclaimed water tank, respectively. Relative proportions of ICC prior to disinfection ranged from $49 \%$ (in raw sewage) to $100 \%$ (in aerobic activated sludge). 


\begin{tabular}{|l|l|l|l|l|l|l|l|l|}
\hline \multicolumn{10}{|c|}{ Average intact cell concentration \% } \\
\hline 49 & 65 & 72 & 66 & 100 & 56 & 88 & 5 & 9 \\
\hline
\end{tabular}

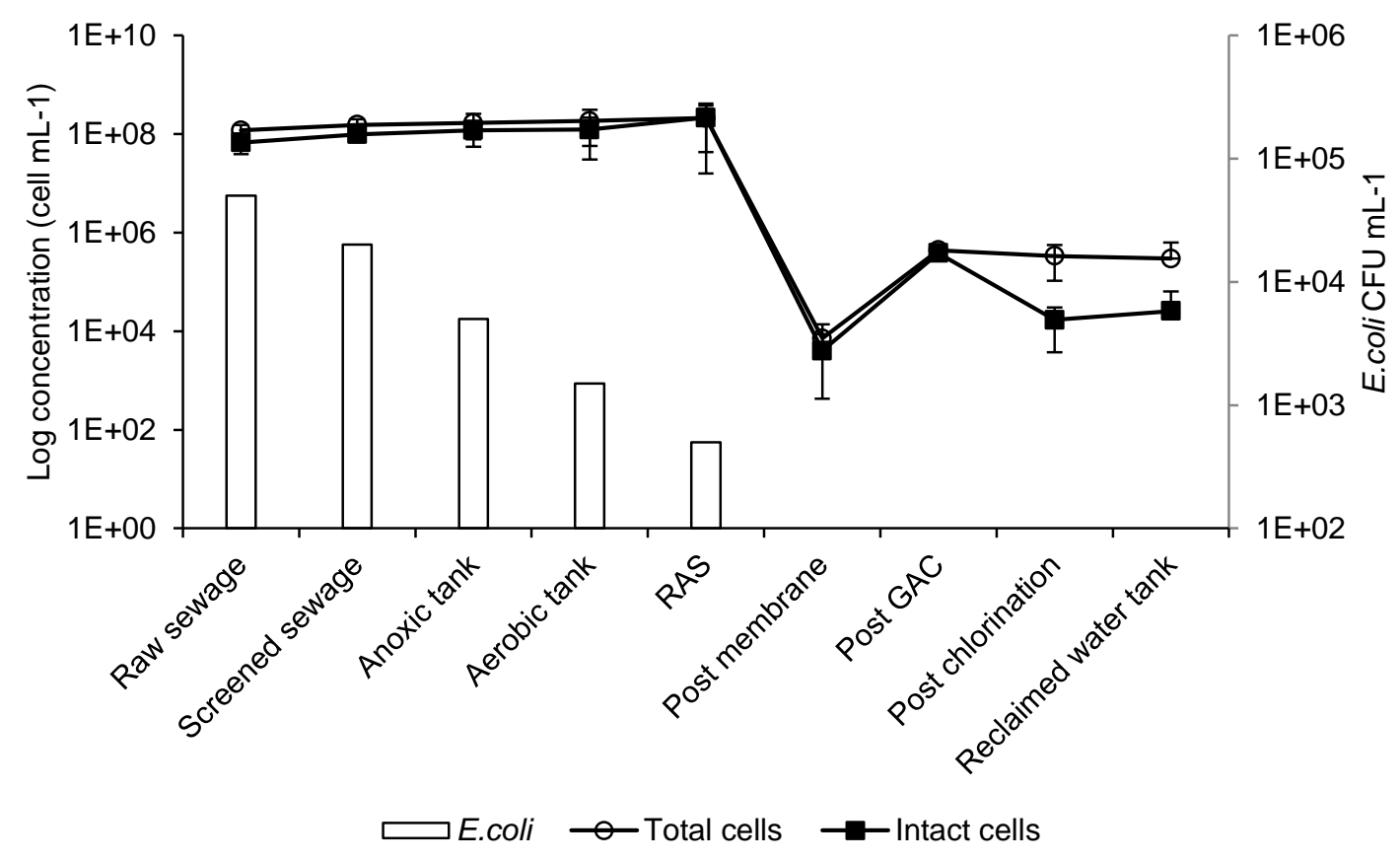

Figure 4. Mean total and intact cell concentrations (as measured by FCM) and E. coli CFU concentrations. Error bars show standard deviations for 5 measurements.

Apart from changes in absolute microbial numbers, flow cytometric density plots and corresponding FL-1 histograms were subject to significant variations along the treatment train as shown for selected samples (Figure 5A and $\mathrm{B}$ ). Compared to raw sewage, microbial signals in gated areas from anoxic tank samples shifted strongly to the left along the FL-1 axis. Although not shown in the typical FL-1 vs. side scatter diagram, these populations correspond to the high nucleic acid (HNA) and low nucleic acid (LNA) signal clusters typically seen for many water types. Whereas HNA dominated in raw sewage, LNA became dominant in the anoxic tank. After being stripped by the membrane the microbial composition was shaped by the biological GAC filter, with both LNA and HNA populations being present in comparable proportions. The fact that different treatment steps induced substantial shifts in staining 
patterns indicates that the microbial community composition and physiological states underwent profound changes. Distributed reclaimed water had an average of $2.9 \times 10^{5}$ total and $1.0 \times 10^{4}$ intact cells per $\mathrm{mL}$ in spring/summer and $1.5 \times 10^{5}$ total and $1.4 \mathrm{x}$ $10^{4}$ intact cells per $\mathrm{mL}$ in winter. 
a) Raw sewage $\left(10^{3}\right.$ dilution $)$

C10 Raw sewage

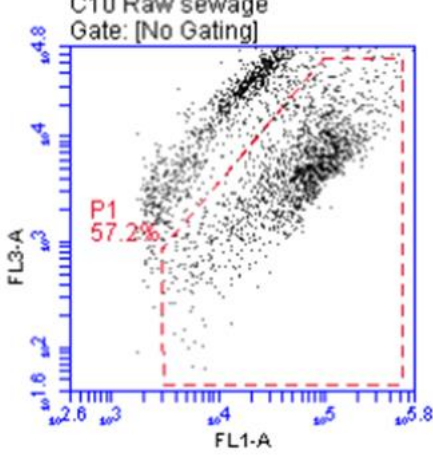

B

a) ICC

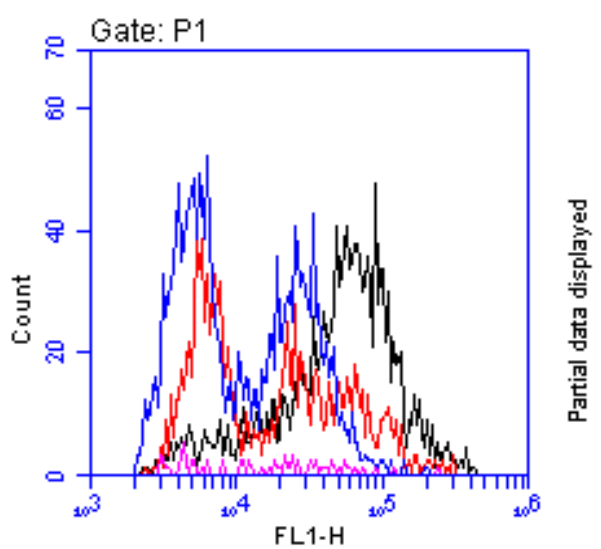

c) Post MBR

C05 Post membrane

A08 Anoxic tank
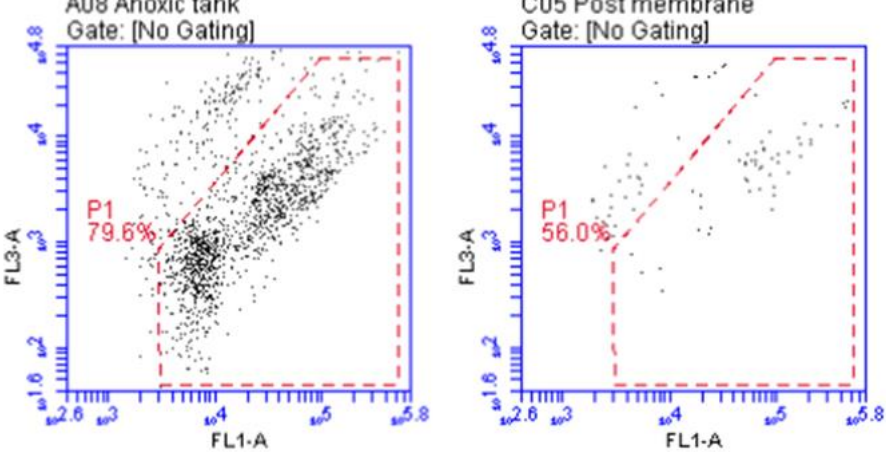

d) Post GAC

C04 Post GAC

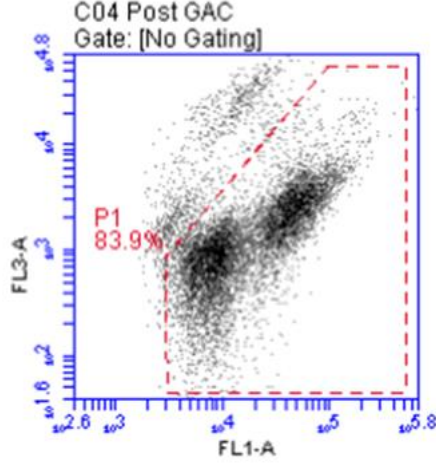

FL1.A e) Reclaimed water tank

C02 Reclaimed water tank

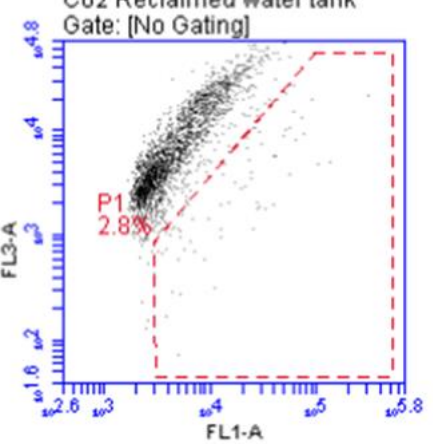

b) TCC

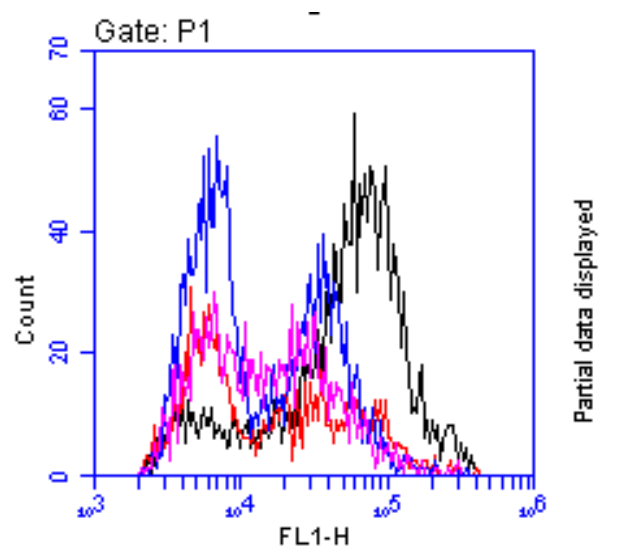

F10 Raw sewage

$\square$ F08 Anoxic

$\square$ F04 Post-GAC

$\square$ F02 Reclaimed water 
Figure 5. Flow cytometric profiles for selected samples along the treatment train after staining with SGPI (A) and corresponding FL-1 histograms (B). (A) Representative density blots of samples at different appropriate dilutions are shown with signals of intact bacteria being located in the gated areas within the dotted lines. Plotting FL-3 (red fluorescence) vs. FL-1 (green fluorescence) enables distinction of different bacterial sub-populations.(B) The change in bacterial clusters is further corroborated by FL-1 histograms (counts vs. green fluorescence) of microbial signals within the gated areas. These histograms are fingerprints that represent shifts in bacterial clusters along the treatment train. To allow comparisons of profiles from samples with very different cell concentrations, the FL-1 histograms are shown only for the first 2,000 events (partial data displayed). 


\subsection{Distribution network}

Changes of microbiological water quality in the distribution system were assessed mainly over the summer months (when there was high water demand) with sporadic sampling also in the winter months (with less water demand). Intact cell concentrations were found to generally increase in the network with increasing distance from the Old Ford WRP. Table 2 shows typical ICC values for spring/summer and autumn/winter obtained after tap-flushing, together with the reduction of intact cell concentrations by the tap flushing itself. The increase in ICC during distribution tended to be stronger in spring/summer (average regrowth of 76 -fold) than in autumn/winter (average regrowth of 47 -fold). Tap flushing brought the most noticeable difference at sampling sites in close proximity to the Old Ford WRP, with less effect observed at distal sampling sites.

Table 2. Typical intact cell concentrations in the distribution network in post-tap flush samples in spring/summer and autumn/winter ( \pm Std dev). Numbers are based on two independent measurements for spring/summer and two independent measurements in autumn/winter. Values refer to the situation prior to flushing events of the entire network. Regrowth factors were calculated from the highest ICC concentrations at distant points compared to works final water.

\begin{tabular}{|c|c|c|c|c|}
\hline \multirow[b]{2}{*}{$\begin{array}{l}\text { Network } \\
\text { sampling } \\
\text { location }\end{array}$} & \multicolumn{2}{|c|}{ Spring/summer } & \multicolumn{2}{|c|}{ Autumn/winter } \\
\hline & $\begin{array}{l}\text { Average ICC } \\
\text { post-tap-flush } \\
\text { (cells } \mathrm{mL}^{-1} \text { ) }\end{array}$ & $\begin{array}{c}\text { Average } \\
\text { reduction } \\
\text { post-tap flush } \\
(\%)\end{array}$ & $\begin{array}{l}\text { Average ICC } \\
\text { post-tap-flush } \\
\text { (cells } \mathrm{mL}^{-1} \text { ) }\end{array}$ & $\begin{array}{c}\text { Average } \\
\text { reduction } \\
\text { post-tap-flush } \\
(\%)\end{array}$ \\
\hline $\begin{array}{l}\text { Reclaimed water } \\
\text { tank prior to } \\
\text { distribution }\end{array}$ & \multicolumn{2}{|c|}{$1.0 \times 10^{4}$} & \multicolumn{2}{|c|}{$1.4 \times 10^{4}$} \\
\hline Site 1 & $2.2 \times 10^{4}\left(1.1 \times 10^{4}\right)$ & 95 & $1.2 \times 10^{4}\left(6.8 \times 10^{3}\right)$ & 73 \\
\hline Site 2 & $4.9 \times 10^{4}\left(3.8 \times 10^{4}\right)$ & 91 & $2.7 \times 10^{4}\left(2.3 \times 10^{4}\right)$ & 81 \\
\hline Site 3 & $1.6 \times 10^{4}\left(5.7 \times 10^{3}\right)$ & 89 & $8.2 \times 10^{4}\left(6.7 \times 10^{4}\right)$ & 80 \\
\hline Site 4 & $1.7 \times 10^{4}\left(3.2 \times 10^{3}\right)$ & 94 & $1.0 \times 10^{5}\left(1.2 \times 10^{5}\right)$ & 65 \\
\hline Site 5 & $2.5 \times 10^{5}\left(3.3 \times 10^{5}\right)$ & 91 & $2.4 \times 10^{5}\left(2.8 \times 10^{5}\right)$ & 40 \\
\hline Site 6 & $6.5 \times 10^{5}\left(1.8 \times 10^{5}\right)$ & 23 & $3.5 \times 10^{5}\left(4.7 \times 10^{5}\right)$ & 35 \\
\hline $\begin{array}{l}\text { Average regrowth } \\
\text { factor }\end{array}$ & \multicolumn{2}{|c|}{ 76-fold } & \multicolumn{2}{|c|}{ 47-fold } \\
\hline
\end{tabular}


To minimise the effect of regrowth in the distribution system, the entire network was subjected to flushing events (up to $20 \mathrm{~m}^{3} \mathrm{~h}^{-1}$ for $20-30$ min in winter) on a regular basis with sampling performed before and after network flushing events. The network flushing effect could decrease absolute ICC numbers by up to $96.9 \%$, but was more noticeable for proximal sampling points than for distal points. The effect of network flushing on relative proportions of intact and damaged bacteria is shown for the spring/summer (Figure 6a) and autumn/winter (Figure 6b) sampling events. Network flushing induced a rise in the proportion of membrane-compromised bacteria for all sites. The more intense flushing regime in autumn/winter was reflected in a stronger shift in proportions of intact and damaged bacteria.

A

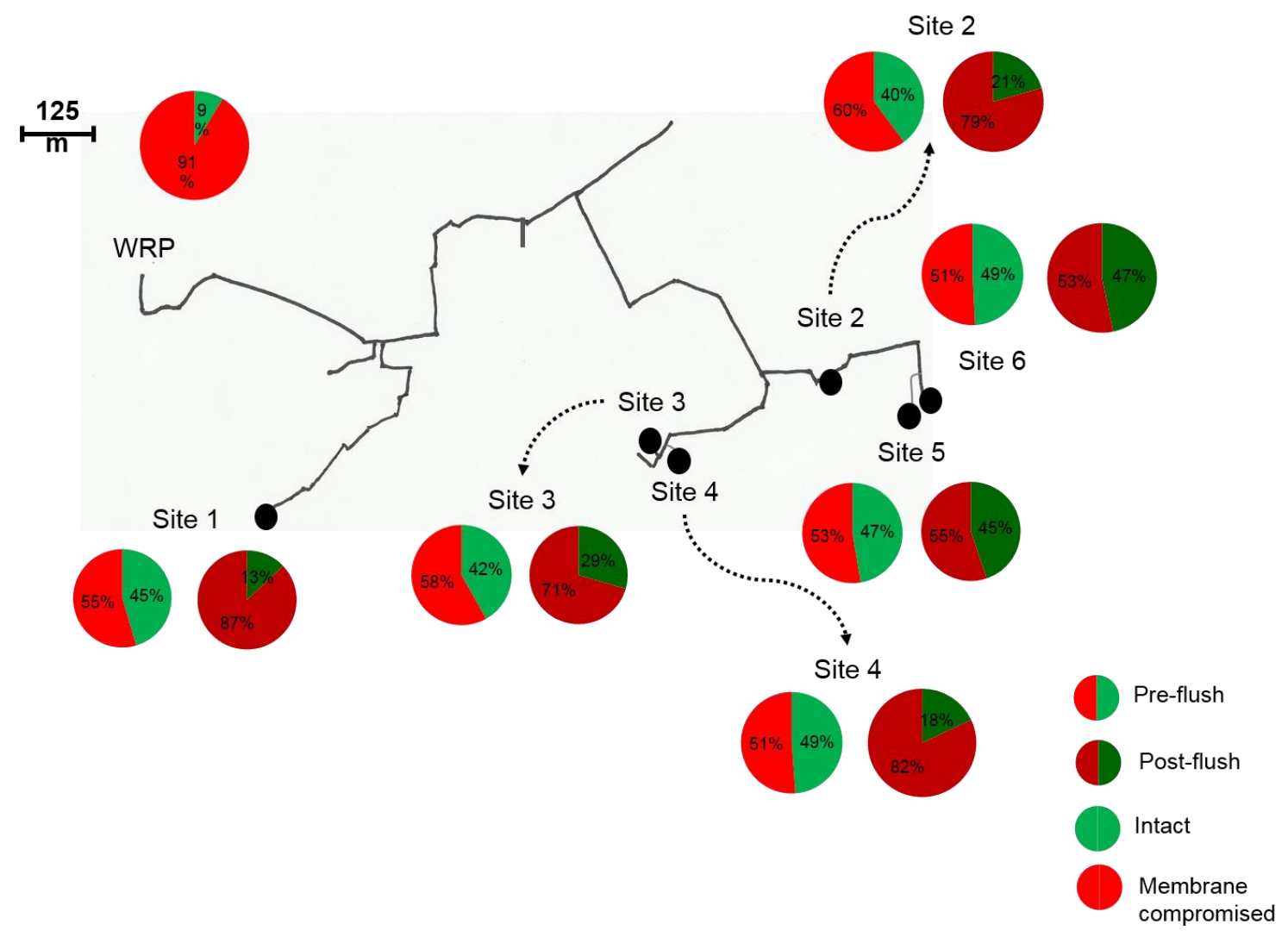




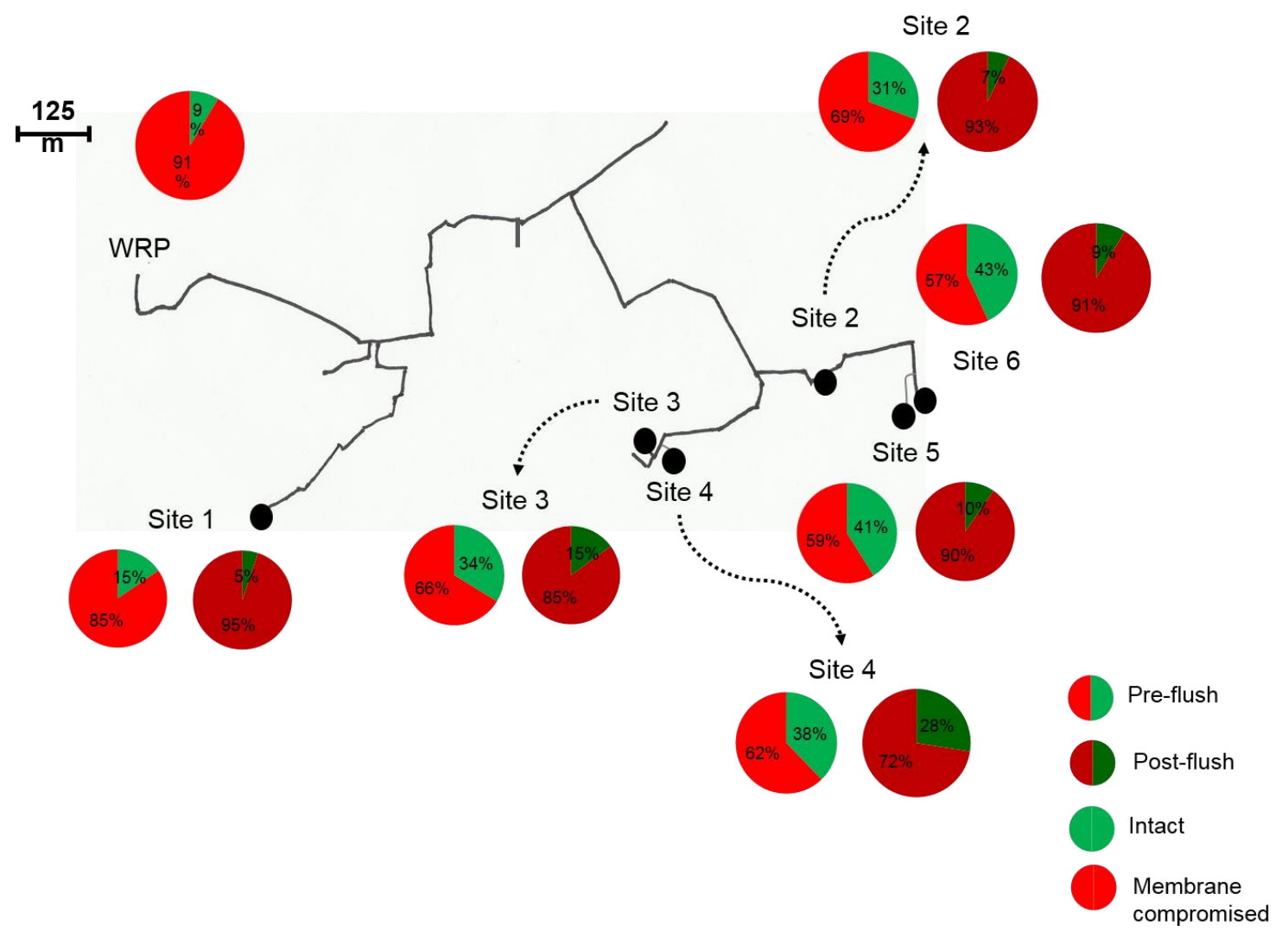

Figure 6. Change in relative proportions of intact and damaged cells induced by network flush events during (A) spring/summer and (B) autumn/winter. Data is shown for samples taken without prior tap-flush.

Independent of seasonal influences, standard microbiological analysis confirmed the absence of faecal coliforms such as E.coli throughout the distribution network, both prior to and post network flush, during the period of the study (data not shown).

\subsection{Water quality parameters and impact of ICC}

To identify factors determining ICC in the distribution system, ICC values were plotted against selected corresponding water quality parameters and $\mathrm{Cl}$ concentrations. No relationships were found between ICC and DOC, TN or SRP (Figure 7A, B and C). A strong relationship existed on the other hand between ICC levels and residual free $\mathrm{Cl}$ (Figure 8). Loss of free $\mathrm{Cl}$ led to an increase in intact cell concentrations. A free $\mathrm{Cl}$ concentration of $0.34 \mathrm{mg} \mathrm{L}^{-1}$ was found necessary to suppress ICC values to the average level of the final treated water from the Old Ford WRP. Elevated ICC values 
found in samples with less $\mathrm{Cl}$ suggested that regrowth could occur when free $\mathrm{Cl}$ concentrations fell below this level.
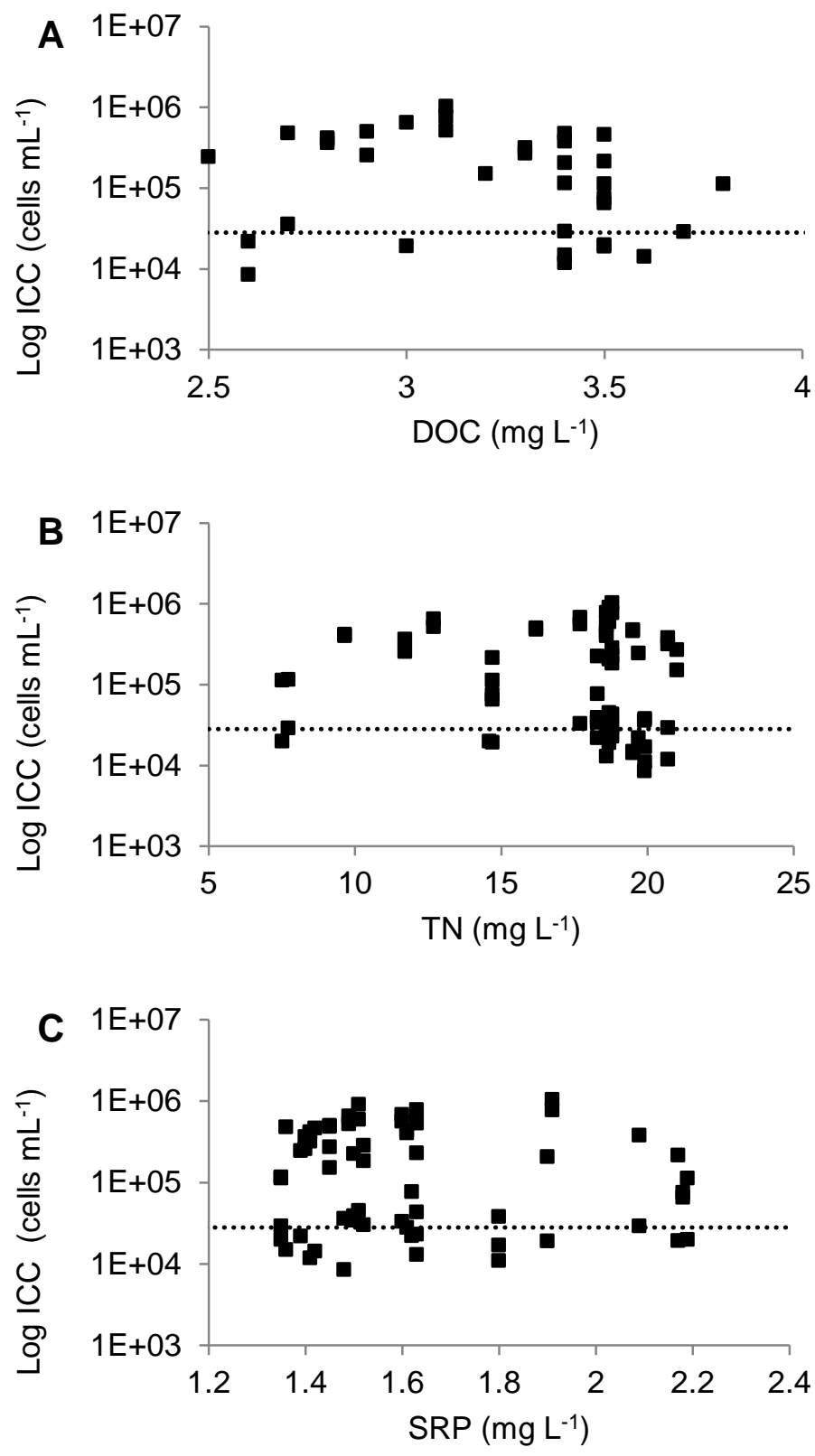

Figure 7. Intact cell concentrations versus (A) DOC, (B) TN and (C) SRP concentrations within the non-potable distribution network. The dashed line (--) indicates the average ICC concentration within the reclaimed water tank prior to distribution. 


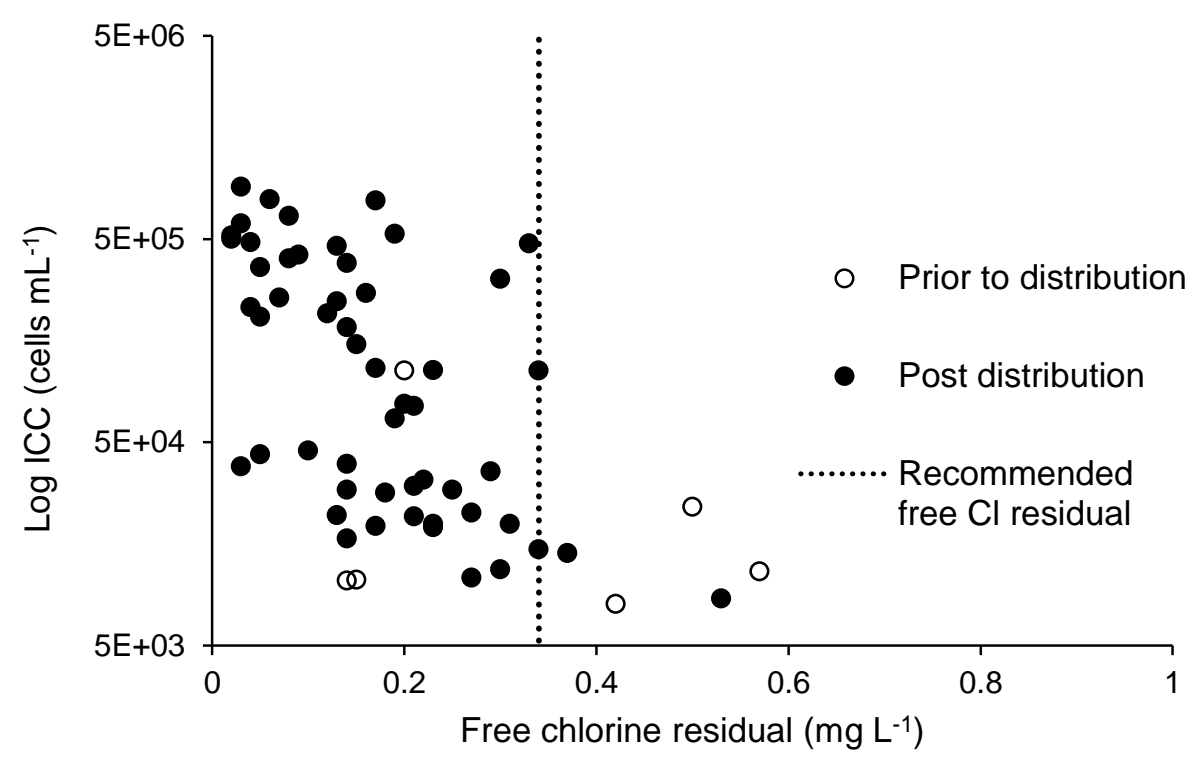

Figure 8. Relationships between free $\mathrm{Cl}$ residual and intact cell concentrations within the distribution network.

\subsection{Conversion of dead bacteria into new biomass}

Bacteria in the samples were analysed by FCM on the day of sampling and, following dechlorination, after seven days of incubation at $22^{\circ} \mathrm{C}$ to assess the extent of possible regrowth. Depending on the initial free $\mathrm{Cl}$ concentrations, FCM patterns initially showed variable proportions of membrane-damaged cells. An example of a sample with low intact cell numbers is shown in Figure 9. At day 0 most bacteria were stained with PI indicating a large proportion of membrane-damaged cells. At day 7 this fraction of damaged bacteria had disappeared with nearly all bacterial signals now being located in the gated region for intact cells after double staining with SG/PI. Results suggest that following dechlorination and storage, the dead biomass was converted into new biomass. Whereas no AOC concentrations were measured in this study, and therefore no nutrient source of regrowth was determined, the example illustrates that dead biomass might be converted into new biomass with high efficiency. 
Day 0
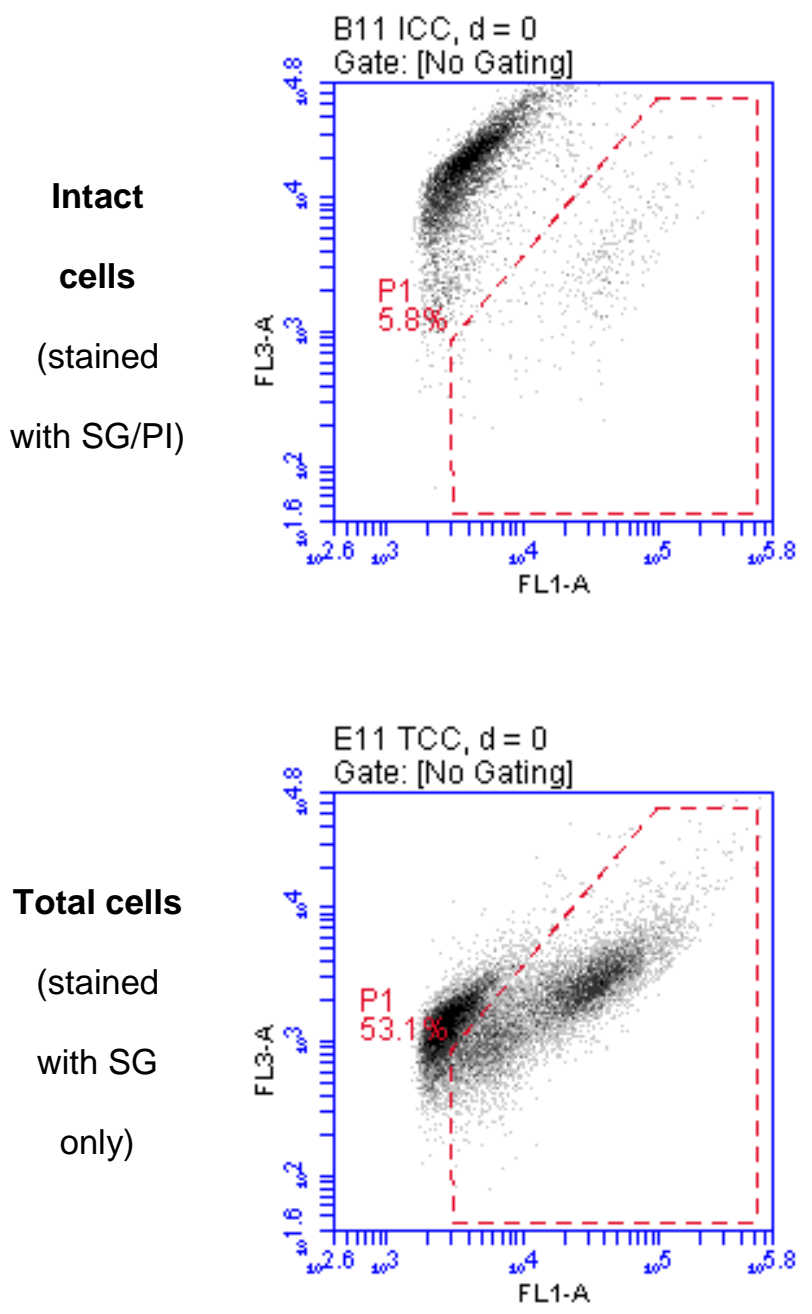

Day 7

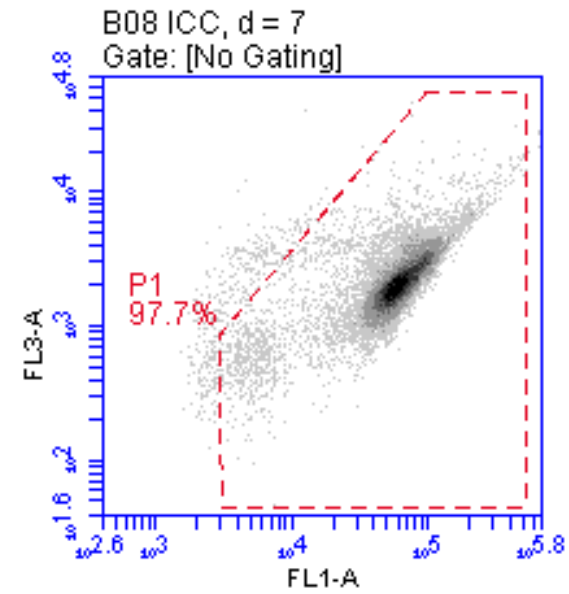

E12 TCC, $d=7$

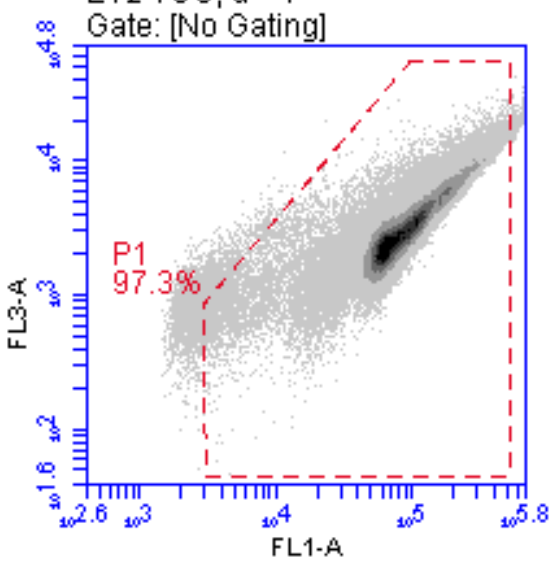

Figure 9 Example of re-growth observed for a dechlorinated network sample (post tapflush). Flow cytometric patterns are shown on the day of sampling (day 0) and after 7 days incubation at $22{ }^{\circ} \mathrm{C}$ in AOC-free glassware. After double staining with SG/PI the gated regions contain only intact cells. After staining with $S G$ the gated regions contain total cells (intact and damaged). Damaged bacteria are dominant at day 0 , whereas intact bacteria prevail after 7 days.

\section{Discussion}

\subsection{Treatment process monitoring.}

Monitoring of the multi-barrier treatment train showed substantial changes in the water microbiology. As expected, the greatest change in bacterial numbers occurred across the membrane resulting in a reduction of $>4$ log units. Considering that background signals tend to generate a base of approx. 200 signals per $\mathrm{ml}$ in flow cytometric 
measurements, this removal rate is rather an underestimation of actual membrane performance (indeed Huang et al. 2016 reported bacterial numbers in MBR effluent below the limit of detection when studying a water reuse system in Southern California). Similar reductions were measured both in summer and winter (data not shown) with higher strength sewage in summer in comparison to winter. Subsequent filtration using GAC on the other hand induced an increase in bacterial numbers. The GAC filter in the plant can be assumed to have a stable microbial community as the carbon dates back to 2012 and at the time of the study was yet to be regenerated or replaced. This observation is consistent with that seen for biologically operated GAC processes used in drinking water treatment (Hammes et al. 2008, Velten et al. 2011, Ho et al. 2012).

Compared to raw sewage, the water treatment process overall reduced the numbers of intact (and potentially 'alive') microorganisms within the raw sewage by 3-4 log units with repeatable performance throughout the sampling period. Considering initial bacterial concentrations of approximately $10^{8}$ cells $\mathrm{mL}^{-1}$, the reduction might appear moderate at first glance, however the microbiology of the distributed water can be considered 'exchanged'. Apart from pure numeric analysis, flow cytometric profiles indicated large changes in the microbiological population especially in the biological steps of the MBR process and after GAC filtration (Figure 5A). The comparison of the fluorescence distribution of SG saturated samples present a simple means for microbiological profiling (Prest et al. 2013), with changes in fluorescence patterns reflecting shifts in the microbial community composition (Prest et al. 2014). These changes are in line with examples from drinking water treatment where passage through GAC resulted in substantially different fluorescence fingerprints (Hammes et al. 2008). Biological filtration processes were found to shape the bacterial communities (Pinto et al. 2013). An exchange of the microbial population can be considered 
essential considering a potentially high load of microbial pathogens in untreated blackwater. Another indication of efficient removal of microorganisms originally present in the sewage across the MBR process comes from the fact both $E$. coli (as a strong indicator of faecal contamination) and coliforms (data not shown) were not detected in the treated water following membrane treatment. The efficient removal of bacterial faecal indicators is in agreement with other studies assessing the efficiency of MBR technology for wastewater recycling. Zanetti et al. (2010) reported a 7 log reduction of faecal coliforms and Purnell et al. (2016), examining the same wastewater system as this study, reported very low bacterial concentrations in the MBR permeate $(<0.3$ CFU/100 mL). Branch et al. (2016) reported that MBR systems could consistently achieve a 4 log removal ( $5^{\text {th }}$ percentile) for bacterial indicators and MBR performance was resilient to a number of hazardous events. Overall results suggest that the used MBR technology is capable of meeting high treatment standards (Hai et al. 2014) which is desired for the treatment of wastewater effluents for water reuse. The water stripped of its initial, hygienically risky microbial population, was subsequently enriched with microbes from the GAC. Chlorination eventually reduced the percentage of membraneintact (and thus potentially viable) bacteria to approx. $5 \%$, which is comparable to the 2-5\% reported for the final works water from three drinking water plants in Riga using chlorination (Nescerecka et al. 2014). The proportion of intact cells increased slightly to $9 \%$ in the storage tank prior to distribution.

\subsection{Distribution network monitoring.}

Concentrations of intact bacteria in the distribution network increased with increasing distance from the plant. Results suggested that the main factor determining cell numbers in a chlorinated system is not the abundance of DOC, SRP or TN, but the concentration of residual free $\mathrm{Cl}$. This is in agreement with previous culture-based studies reporting the disinfectant residual to be the most important factor determining 
the levels of HPCs (Zhang and DiGiano 2002). Unlike in non-chlorinated distribution systems, the presence of the disinfectant restrains the consumption of $A O C$ and prevents the conversion of available AOC into microbial biomass (Liu et al. 2015), thus the water is not biologically stable once the $\mathrm{Cl}$ is depleted. Increases in intact cell numbers have also been reported for the chlorinated drinking water distribution system of Riga, Latvia (Nescerecka et al. 2014, 2018). At one particular sampling point in Riga (water age of 32-50 hours, Nescerecka et al. 2018) an increase in intact cell concentration of approximately 4.6-9.0-fold was reported. Whereas no maximal increases at the most distant points of the distribution system were reported in the case of Riga, overall increases of up to approx. $40-80$-fold could be measured in this study at the points furthest from the WWTWs. As for our system, the reason for regrowth in the Riga network was also explained by the loss of $\mathrm{Cl}$ residual (apart from temperature effects and nutrient availability, Nescerecka et al. 2018). Free $\mathrm{Cl}$ residual at the three drinking water works feeding the distribution system in Riga ranged between 0.42 to $0.51 \mathrm{mg} \mathrm{L}^{-1}$. Increases in ICC were possible when the residual fell below $0.2 \mathrm{mg} \mathrm{L}^{-1}$ (Nescerecka et al. 2018). Other studies (using culturability as a diagnostic basis) have reported bacterial regrowth at $\mathrm{Cl}$ concentrations lower than $0.1 \mathrm{mg} \mathrm{L}^{-1}$ (Niquette et al. 2001) or $0.07 \mathrm{mg} \mathrm{L}^{-1}$ (Francisque et al. 2009). It should be noted that the presence of intact bacteria does not necessarily entail the presence of culturable cells, as bacterial integrity is a more conservative viability parameter than the ability to form colonies. In a drinking water system in Scotland (using flow cytometry like in the study in Riga), the critical free $\mathrm{Cl}$ concentration was determined to be approximately $0.5 \mathrm{mg} \mathrm{L}^{-1}$ (Gillespie et al. 2015). This value was somewhat higher than the $0.34 \mathrm{mg} \mathrm{L}^{-1}$ reported here. Disinfectant levels above these thresholds were always associated with low proportions of intact cells, whereas a drop below this threshold could (but did not have to) result in substantially higher percentages of intact cells. The exact thresholds can be assumed to depend on a complex interaction of biological, chemical and physical water 
parameters (Zhang \& DiGiano 2002). Also different microbial communities in different distribution systems might show variations in their susceptibilities to $\mathrm{Cl}$ as not all the microbes respond equally (Nocker et al. 2017). The composition of the bacterial population in the recycled water distribution system of this study remains to be assessed as well as the extent to which it undergoes change, as seen for potable distribution systems (Pinto et al. 2014; Prest et al. 2014). When comparing the reclaimed water distribution system assessed here with drinking water distribution systems, the networks can be considered to be very distinct. For example, the persistence of disinfectant residual, differences in nutrient levels and the composition of the $\mathrm{AOC}$ pool, water consumption, resulting residence time and consumption evenness throughout the network can be assumed to be very different. Other factors might include differences in water temperatures (influenced by pipe depths and climatic factors).

\subsection{Dead biomass as potential contributor to regrowth.}

Once free $\mathrm{Cl}$ is depleted, the extent of regrowth is typically determined by the given temperature and available nutrients whose levels would depend on the underlying water treatment process and the source water quality (Nescerecka et al. 2018). In the drinking water distribution system of Brussels that is fed by treated surface water and various groundwaters, it was shown that the parts of the system with groundwaters were less susceptible to bacterial regrowth (Niquette et al. 2001). It was recently, however, reported that in a non-chlorinated potable distribution system, cell concentrations in the network and $A O C$ levels in the plant effluent were inversely related (Prest et al. 2016). Underlying a carbon mass balance, carbon was either fixed in $A O C$ or in the bacterial biomass with the conversion rate mainly governed by temperature. An attractive field of research in the future might be in determining how much dead biomass contributes to the available AOC pool. Dead biomass is abundant 
in disinfected water and contains nutrients in exactly the composition that is required by the new biomass. Dead biomass might be more accessible as a nutrient source, when present in a membrane-damaged form, compared to UV-disinfection that does not impact bacterial membranes in the applied dose range. The situation resembles a position identified in dental biofilm research, where the use of antimicrobial agents embedded in toothpastes and mouth rinses was reported to result in an 'oral microbial massacre with high amounts of dead bacteria in close proximity to few surviving bacteria' (Herrero et al. 2017). In water systems, necrotrophic feeding has so far been described for Legionella pneumophila (Temmerman et al. 2006), however new discoveries in this field are very likely.

\section{Conclusions}

This study on the treatment of blackwater showed that the technology of MBR combined with GAC and subsequent disinfection is capable of a strong overall reduction of intact bacteria compared to raw sewage. Bacterial removal furthermore went along with profound changes in flow cytometric microbial profiles indicating an exchange of the hygienically critical bacterial community. The MBR resulted in $>4$ log reduction in bacterial numbers and an E.coli and coliform free permeate. In the water distribution network intact cell concentrations typically increased towards the distal parts of the network. A strong correlation between intact cell numbers and free residual $\mathrm{Cl}$ was observed. A free $\mathrm{Cl}$ residual of $>0.34 \mathrm{mg} \mathrm{L}^{-1}$ was identified as necessary for this particular distribution system for suppression of regrowth. Biweekly system flushing was confirmed to be an efficient means to maintain the $\mathrm{Cl}$ residual and to keep regrowth low. Cannibalistic conversion of dead biomass into new biomass was seen during regrowth. Overall FCM was helpful for characterisation of the treatment process and network hygiene and enabled informed maintenance/operation strategies. 


\section{Acknowledgements}

The research leading to these results has received funding from the European Community's Seventh Framework Programme (FP7/2013-2016) under grant agreement number 619040 (DEMOWARE) and support from Thames Water Utilities Ltd. The authors also express gratitude to Craig Brewer for his support in sample analysis during his placement year.

\section{References}

Angelakis, A.N., and Gikas, P., (2014). "Water reuse: Overview of current practices and trends in the world with emphasis to EU states", Water Utility Journal, vol. 8: pp 67-78.

Berney, M., Hammes, F., Bosshard, F., Weilenmann, H.-U and Egli, T., (2007). "Assessment and Interpretation of Bacterial Viability by Using the LIVE/DEAD BacLight Kit in combination with flow cytometry", Applied and Environmental Microbiology, vol. 73, pp 3283-3290.

Besmer, M.D., Epting, J., Page, R. M., Sigrist, J. A., Huggenberger, P., and Hammes, F., (2016). "Online flow cytometry reveals microbial dynamics influenced by concurrent natural and operational events in groundwater used for drinking water treatment". Scientific Reports, vol 6.

Branch, A., Trinh, T., Carvajal, G., Leslie, G., Coleman, H.M., Stuetz, R.M. et al. (2016). Hazardous events in membrane bioreactors-Part 3: Impacts on microorganism log removal efficiencies. Journal of Membrane Science 497, pp. 514-523.

Francisque, A., Rodriguez, M.J., Miranda-Moreno, L.F., Sadiq, R., and Proulx, F., (2009). "Modeling of heterotrophic bacteria counts in a water distribution system". Water Research, vol. 43, no. 4, pp. 1075-1087.

Gatza, E., Hammes F. and Prest E,. (2013). "Assessing water quality with the BD Accuri ${ }^{\text {TM }}$ C6 flow cytometer". White Paper BD Biosciences.

Gillespie, S., Lipphaus, P., Green, J., Parsons, S., Weir, P., Juskowiak, K., Jefferson, B., Jarvis, P. and Nocker, A., (2014), "Assessing microbiological water quality in drinking water distribution systems with disinfectant residual using flow cytometry", Water Research, vol. 65, pp. 224-234. 
Goodwin, D., Raffin, M., Jeffrey, P. and Smith, H.M., (2017). Evaluating media framing and public reactions in the context of a water reuse proposal. International Journal of Water Resources Development, pp.1-21.

Hai, F. I., Riley, T., Shawkat, S., Magram, S.F., and Yamamoto, K., (2014). "Removal of pathogens by membrane bioreactors: a review of the mechanisms, influencing factors and reduction in chemical disinfectant dosing". Water, vol. 6, no. 12, pp. 3603-3630.

Hammes, F., and Egli, T., (2007), "A flow cytometric method for AOC determination", sta, vol. 20, pp. 30.

Hammes, F., Berney, M., Wang, Y., Vital, M., Köster, O. and Egli, T., (2008). "Flowcytometric total bacterial cell counts as a descriptive microbiological parameter for drinking water treatment processes". Water Research, vol. 42, pp. 269-277.

Hammes, F., Broger, T., Weilenmann, H.-U., Vital, M., Helbing, J., Bosshart, U., Huber, P., Peter Odermatt, R. and Sonnleitner, B., (2012). "Development and laboratoryscale testing of a fully automated online flow cytometer for drinking water analysis". Cytometry, vol. 81A, pp. 508-516.

Herrero, E.R., Boon, N., Pauwels, M., Bernaerts, K., Slomka, V., Quirynen, M., and Teughels, W., (2017). "Necrotrophic growth of periodontopathogens is a novel virulence factor in oral biofilms". Scientific Reports, vol. 7.

Hill, S., and James, C., (2014). The Queen Elizabeth Olympic Park water recycling system, London. In: Ali Memon, F., Ward, S. (Eds.), Alternative Water Supply Systems. International Water Association Publishing, London, pp. 309-328.

Ho, L., Bruan, K., Fabris, R., Hoefel, D., Morran, J., Monis, P. and Drikas, M., (2012). "Comparison of drinking water treatment process streams for optimal bacteriological water quality”. Water Research, vol 46, no. 12, pp 3934-3942.

Højris, B,. Boesgaard Christensen, S.C., Albrechtsen, H-J., Smith, C., and Dahlqvist, M., (2016). "A novel, optical, on-line bacteria sensor for monitoring drinking water quality". Scientific Reports, vol 6: 23935.

Huang, X., Zhao, Z., Hernandez, D. and Jiang, S,C., (2016) "Near real-time flow cytometry monitoring of bacterial and viral removal efficiencies during water reclamation processes". Water, vol. 8, no. 10, pp 1-11.

Hurlimann, A., Hes, D., Othman, M., and Grant, T., (2007) "Charting a new course of water - is black water reuse sustainable?". Water Science and Technology: Water Supply, vol 7, pp. 109-118.

Knerr, H., Rechenburg, A., Kistemann, T., and Schmitt, T.G., (2011). "Performance of a MBR for the treatment of blackwater". Water Science and Technology, vol 63, pp. 1247-1254.

Knight, H., Maybank, R., Hannan, P., King, D., and Rigley, R., (2012). Lessons learned during the London 2012 Games construction project. 
Lipphaus, P., Hammes, F., Kötzsch, S., Green, J., Gillespie, S. and Nocker, A., (2014). "Microbiological tap water profile of a medium-sized building and effect of water stagnation", Environmental Technology, vol. 35, no. 5, pp. 620-628.

Liu, X., Wang, J., Liu, T., Kong, W., He, X., Jin, Y. and Zhang, B., (2015). Effects of assimilable organic carbon and free chlorine on bacterial growth in drinking water. PloS one, vol. 10, no. 6, e0128825.

Nescerecka, A., Juhna, T., and Hammes, F., (2018). Identifying the underlying causes of biological instability in a full-scale drinking water supply system. Water Research, vol. 135, pp. 11-21.

Nescerecka, A., Rubulis, J., Vital, M., Juhna, T., and Hammes, F., (2014). "Biological instability in a chlorinated drinking water distribution network". PLOS ONE, vol 9, iss 5: e96354.

Niquette, P., Servais, P., and Savoir, R., (2001). "Bacterial dynamics in the drinking water distribution system of Brussels". Water Research, vol. 35, no. 3, pp. 675682.

Nocker, A., Cheswick, R., Dutheil de la Rochere, P. M., Denis, M., Léziart, T., and Jarvis, P., (2017). "When are bacteria dead? A step towards interpreting flow cytometry profiles after chlorine disinfection and membrane integrity staining". Environmental Technology, vol. 38, no. 7, pp. 891-900.

Pinto, A. J., Schroeder, J., Lunn, M., Sloan, W., and Raskin, L., (2014). "Spatialtemporal survey and occupancy-abundance modeling to predict bacterial community dynamics in the drinking water microbiome". mBio, vol. 5, no. 3: e01135-14.

Pinto, A. J., Xi, C., and Raskin, L., (2012). "Bacterial community structure in the drinking water microbiome is governed by filtration processes". Environmental Science and Technology, vol. 46, no. 16, pp. 8851-8859.

Prest, E.L., Weissbrodt, D.G., Hammes, F., van Loosdrecht, M.C.M, and Vrouwenvelder, J.S., (2016). "Long-Term Bacterial Dynamics in a Full-Scale Drinking Water Distribution System”. PLOS ONE, vol. 11, no. 10:e0164445.

Prest, E.I., El-Chakhtoura, J., Hammes, F., Saikaly, P.E., Van Loosdrecht, M.C.M., and Vrouwenvelder, J.S., (2014). "Combining flow cytometry and 16S rRNA gene pyrosequencing: a promising approach for drinking water monitoring and characterization". Water Research, vol. 63, pp. 179-189.

Prest, E.I., Weissbrodt, D.G., Hammes, F., van Loosdrecht, M.C.M., and Vrouwenvelder, J.S., (2016). "Long-term bacterial dynamics in a full-scale drinking water distribution system”. PLoS One, vol. 11, no. 10, e0164445.

Prest, E., Hammes, F., Kötzsch, S., Van Loosdrecht, M. and Vrouwenvelder, J., (2013), "Monitoring microbiological changes in drinking water systems using a fast and reproducible flow cytometric method". Water Research, vol. 47, no. 19, pp. 71317142. 
Purnell, S., Ebdon, J., Buck, A., Tupper, M., and Taylor, H., (2015). "Bacteriophage removal in a full-scale membrane bioreactor (MBR) - Implications for wastewater reuse". Water Research, vol. 73, pp. 109-117.

Quevauviller , P., Thomas, O., and van der Beken A., (2007). Wastewater quality monitoring and treatment. Wiley.

Ramseier, M.K., von Gunten, U., Freihofer, P., and Hammes, F., (2011). "Kinetics of membrane damage to high (HNA) and low (LNA) nucleic acid bacterial clusters in drinking water by ozone, chlorine, chlorine dioxide, monochloramine, ferrate $(\mathrm{VI})$, and permanganate". Water Research, vol. 45, no. 3, pp. 1490-500.

Smith, H.M., Rutter, P., and Jeffrey, P. (2015). "Public perceptions of recycled water: a survey of visitors to the London 2012 Olympic Park". Journal of Water Reuse and Sanitation, vol. 5, no, 2, pp. 189-195.

Temmerman, R., Vervaeren, H., Noseda, B., Boon, N., and Verstraete, W., (2006). "Necrotrophic growth of Legionella pneumophila". Applied and Environmental Microbiology, vol. 72, no. 6, pp. 4323-4328.

US EPA. (2004), Guidelines for water reuse. http://www.ehproject.org/PDF/ehkm/water-reuse2004.pdf

Velten, S., Boller, M., Köster, J., Helbing, J., Weilenmann, H.U., and Hammes, F., (2011). "Development of biomass in a drinking water granular active carbon (GAC) filter". Water Research, vol 41, no. 9, pp. 1973-1983.

Zanetti, F., De Luca, G., and Sacchetti, R., (2010). "Performance of a full-scale membrane bioreactor system in treating municipal wastewater for reuse purposes". Bioresource Technology, vol. 101, no. 10, pp. 3768-3771.

Zhang, W., and DiGiano, F.A. (2002). "Comparison of bacterial regrowth in distribution systems using free chlorine and chloramine: a statistical study of causative factors". Water Research, vol. 36, no. 6, pp. 1469-1482 